\title{
Prevalence and subtypes of Influenza A Viruses in Wild Waterfowl in Norway 2006-2007
}

\author{
Anna Germundsson*1, Knut I Madslien'1, Monika Jankowska Hjortaas' ${ }^{1}$ Kjell Handeland ${ }^{1}$ and \\ Christine Monceyron Jonassen 1,2
}

\begin{abstract}
The prevalence of influenza A virus infection, and the distribution of different subtypes of the virus, were studied in 1529 ducks and 1213 gulls shot during ordinary hunting from August to December in two consecutive years, 2006 and 2007, in Norway. The study was based on molecular screening of cloacal and tracheal swabs, using a pan-influenza A RT-PCR. Samples found to be positive for influenza A virus were screened for the H5 subtype, using a H5 specific RT$P C R$, and, if negative, further subtyped by a RT-PCR for the 3'-part of the hemagglutinin (HA) gene, encompassing almost the entire $\mathrm{HA} 2$, and the full-length of the neuraminidase (NA) gene, followed by sequencing and characterization. The highest prevalence (12.8\%) of infection was found in dabbling ducks (Eurasian Wigeon, Common Teal and Mallard). Diving ducks (Common Goldeneye, Common Merganser, Red-breasted Merganser, Common Scoter, Common Eider and Tufted Duck) showed a lower prevalence (4.1\%). In gulls (Common Gull, Herring Gull, Black-headed Gull, Lesser Black-headed Gull, Great Black-backed Gull and Kittiwake) the prevalence of influenza A virus was 6.1\%. The infection prevalence peaked during October for ducks, and October/November for gulls. From the 16 hemagglutinin subtypes known to infect wild birds, 13 were detected in this study. Low pathogenic H5 was found in 17 dabbling ducks and one gull.
\end{abstract}

\section{Findings}

Birds of wetlands and aquatic environments constitute the major natural reservoir of influenza A viruses of all hemagglutinin (HA) and neuraminidase (NA) subtypes (H1-H16 and N1-N9) [1,2]. In particular, birds belonging to Anseriformes (ducks, geese and swans) and Charadriiformes (gulls, terns and waders) have been reported to be efficient hosts. The birds do not usually develop clinical disease, but they shed a large number of virus particles in their faeces, which may cause serious disease outbreaks when introduced into poultry flocks. The prevalence of avian influenza A viruses in their natural hosts depends on geographical location, season, year and host species. For instance, in Sweden the prevalence of influenza A viruses in Mallards were 3-fold higher as compared to the Netherlands during the same time of the year [3]. Following the outbreak of highly-pathogenic avian influenza (HPAI) H5 at Qinghai Lake in China in 2005, where 10 000 wilds geese and ducks died, there has been an

* Correspondence: Anna.Germundsson@vetinst.no

${ }^{1}$ Department of Animal Health, National Veterinary Institute, P.O Box 750 Sentrum. N-0106 Oslo, Norway

Full list of author information is available at the end of the article increased focus on wild birds as carriers of the HPAI H5 contributing to geographical spread of the virus, and as source of infection for poultry [4-6]. In Norway, an active surveillance program on influenza A viruses in wild waterfowl was started in 2005 [7]. In this study, we present the results of this program during the subsequent years 2006 and 2007.

Cloacal and tracheal swabs were collected from a total of 2742 birds. The sampling included 1480 samples from three species of dabbling ducks, 49 samples from six species of diving ducks and 1213 samples from six gull species (Table 1). The samples were collected from birds shot during the licenced hunting season from August to December in 2006 and 2007, in four different counties in Norway known to have high densities of poultry and being important stop-over locations for migrating ducks (Figure 1). From each bird, cloacal and tracheal swabs were collected, pooled by placing the two swabs in the same virus transport medium and sent to the laboratory by postal mail. At arrival in the laboratory, $200 \mu \mathrm{l}$ of the medium were used for RNA extraction and the rest was stored at $-80^{\circ} \mathrm{C}$. RNA was extracted using the automatic 


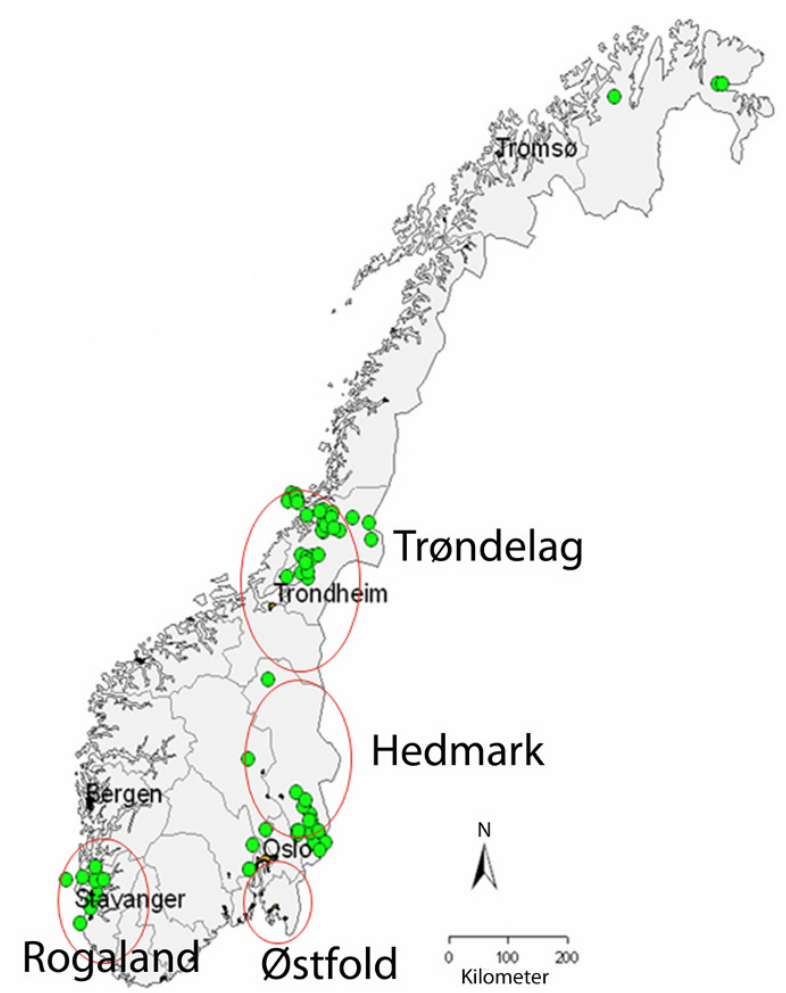

Figure 1 Geographical location of sampling regions (counties) for wild waterfowl examined for influenza $A$ virus in Norway in 2006 and 2007. The red rings illustrate locations where birds were sampled. The green spots show important stop-over locations for migrating ducks.

extraction instrument NucliSens' easyMag ${ }^{\mathrm{mt}}$ (bioMérieux bv, Boxtel, The Netherlands) according to the manufacturer's instruction, and eluted in $55 \mu \mathrm{l}$. Detection of influenza A virus was performed using primers and probe targeting part of the 5 '-end of the Matrix gene [8]. Amplification was performed on a Stratagene Mx3500P (LaJolla, CA, USA) using the Qiagen One-Step RT-PCR kit (Qiagen, West Sussex, UK), with $0.4 \mu \mathrm{M}$ of each primer, $0.3 \mu \mathrm{M}$ of probe, and a $\mathrm{MgCl}_{2}$ concentration of $1.25 \mathrm{mM}$. The RT step was run for $30 \mathrm{~min}$ at $50^{\circ} \mathrm{C}$, followed by $15 \mathrm{~min}$ at $95^{\circ} \mathrm{C}$. A three-step PCR cycling protocol was used using the following conditions: 45 cycles of $94^{\circ} \mathrm{C}$ for $15 \mathrm{~s}, 55^{\circ} \mathrm{C}$ for $30 \mathrm{~s}$ and $72^{\circ} \mathrm{C}$ for $15 \mathrm{~s}$. Samples with a ct-value of 38 or below were considered to be positive for influenza A virus. Influenza A positive samples were further tested for H5 subtype [9]. Samples found to be positive for influenza A virus, but negative for subtype H5, were subtyped by performing RT-PCRs and sequencing for the HA2 and full-length NA genes [10,11]. The nucleotide sequences obtained in this study were deposited in the EMBL database (EMBL: FM179753FM179764, EMBL:FN773066-FN773082). A few samples were selected for virus isolation in embryonated chicken eggs (data not shown).

The prevalence of influenza A virus in wild birds in Norway in 2006 and 2007 are presented in Table 1. High prevalence of infection was found in dabbling ducks (189/ $1480,12.8 \%$ ), whereas lower prevalence were seen in diving ducks $(2 / 49,4.1 \%)$ and gulls $(74 / 1213,6.1 \%)$. The finding of a higher prevalence in dabbling compared to diving ducks is consistent with results found in other studies [2,3,12]. Virus in faeces from infected birds is excreted into the surface water and may more efficiently be transmitted to dabbling ducks feeding there, as compared to diving ducks feeding at deeper water levels. It has been shown that influenza viruses can remain infectious in the surface water for several days $[13,14]$.

The prevalence of influenza A virus in wild birds varied between the two years of study. In Mallards the prevalence was similar, 13.9\% (50/359) in 2006 and 14.9\% (79/ $527)$ in 2007. In Common Teal the prevalence altered from 6\% (6/100) in 2006 to $15.9 \%$ (38/238) in 2007, and in gulls from $3.7 \%$ (22/596) in 2006 to 8.5\% (52/614) in 2007 (Table 2). In 2005, the prevalence in Mallards and Common Teal were of $20.4 \%(58 / 284)$ and $30.9 \%(13 / 42)$ respectively [7]. A possible explanation for the lowered observed prevalence in 2006 could be due to climatic variations. The summer of 2006 was exceptionally warm, and especially the water temperature in lakes and sea was elevated. It has been shown that the survival of influenza A virus in water decreases for water temperature above 17 degrees, that only rarely are achieved in lakes in Norway [13]. In both sampling years, the highest prevalence for ducks was seen in October, whereas in gulls the peak prevalence varied between October (2006) and November (2007) (Table 2). The high prevalence seen in ducks in October may be a result of the close contact, and possibility of virus transmission between individuals, following the dense aggregation of these birds along their migratory route towards wintering areas.

From a total of 263 birds testing positive for influenza A virus, the HA subtype was successfully determined in 127 samples from ducks and 39 samples from gulls (Figure 2). The subtype H5 was found in 22 birds, and further sequencing of the cleavage site of the HA gene identified all of them as low-pathogenic strains (LPAI). Seventeen of these samples were detected in Mallards, one in Eurasian Wigeons, three in Common Teals, and one in Herring Gulls. A great number of subtypes were detected in ducks; H1-H6 and H8-H12 were detected in Mallards, H1, H3-H6, H8, H9 and H12 in Common Teals, and H1, H5, H6 and H9 in Eurasian Wigeons. The most frequently detected subtypes in ducks in 2006 were $\mathrm{H} 4$ and $\mathrm{H} 12$, whereas subtypes $\mathrm{H} 1$ and $\mathrm{H} 6$ were most prevalent 
Table 1: Overview of wild waterfowl sampled for influenza A virus examination in Norway 2006 and 2007

\begin{tabular}{|c|c|c|c|c|c|c|}
\hline & Species & & $\begin{array}{c}\text { No. of birds } \\
\text { analysed } \\
2006\end{array}$ & $\begin{array}{c}\text { No. of positive } \\
\text { birds (\%) } \\
2006\end{array}$ & $\begin{array}{c}\text { No. of birds } \\
\text { analysed } \\
2007\end{array}$ & $\begin{array}{c}\text { No. of positive } \\
\text { birds (\%) } \\
2007\end{array}$ \\
\hline \multirow[t]{3}{*}{$\begin{array}{l}\text { Dabbling } \\
\text { ducks }\end{array}$} & Anas penelope & $\begin{array}{l}\text { Eurasian } \\
\text { Wigeon }\end{array}$ & 137 & $4(2.9)$ & 119 & $12(10.1)$ \\
\hline & Anas crecca & Common Teal & 100 & $6(6.0)$ & 238 & $38(15.9)$ \\
\hline & $\begin{array}{c}\text { Anas } \\
\text { platyrhynchos }\end{array}$ & Mallard & 359 & $50(13.9)$ & 527 & $79(14.3)$ \\
\hline \multirow[t]{6}{*}{$\begin{array}{l}\text { Diving } \\
\text { ducks }\end{array}$} & $\begin{array}{c}\text { Bucephala } \\
\text { clangula }\end{array}$ & $\begin{array}{l}\text { Common } \\
\text { Goldeneye }\end{array}$ & 15 & 0 & 4 & 0 \\
\hline & $\begin{array}{c}\text { Mergus } \\
\text { merganser }\end{array}$ & $\begin{array}{l}\text { Common } \\
\text { Merganser }\end{array}$ & 7 & 0 & 0 & 0 \\
\hline & $\begin{array}{l}\text { Mergus } \\
\text { serrator }\end{array}$ & $\begin{array}{l}\text { Red-breasted } \\
\text { Merganser }\end{array}$ & 6 & 0 & 1 & 0 \\
\hline & $\begin{array}{l}\text { Melanitta } \\
\text { nigra }\end{array}$ & $\begin{array}{l}\text { Common } \\
\text { Scoter }\end{array}$ & 2 & 0 & 1 & 0 \\
\hline & $\begin{array}{l}\text { Somateria } \\
\text { mollissima }\end{array}$ & $\begin{array}{l}\text { Common } \\
\text { Eider }\end{array}$ & 0 & 0 & 9 & $2(22.2)$ \\
\hline & Aythya fuligula & Tufted Duck & 0 & 0 & 4 & 0 \\
\hline \multirow[t]{6}{*}{ Gulls } & Larus canus & Common Gull & 173 & $6(3.5)$ & 211 & $19(9.0)$ \\
\hline & $\begin{array}{c}\text { Larus } \\
\text { argentatus }\end{array}$ & Herring Gull & 363 & $10(2.8)$ & 328 & $30(9.1)$ \\
\hline & $\begin{array}{l}\text { Larus } \\
\text { ridibundus }\end{array}$ & $\begin{array}{c}\text { Black-headed } \\
\text { Gull }\end{array}$ & 19 & $4(21.1)$ & 11 & $1(9.1)$ \\
\hline & Larus fuscus & $\begin{array}{l}\text { Lesser Black- } \\
\text { headed Gull }\end{array}$ & 8 & 0 & 0 & 0 \\
\hline & Larus marinus & $\begin{array}{l}\text { Great Black- } \\
\text { headed Gull }\end{array}$ & 34 & $2(5.8)$ & 64 & $2(3.1)$ \\
\hline & Rissa tridactyla & Kittiwake & 2 & 0 & 0 & 0 \\
\hline TOTAL & $\begin{array}{l}\text { Dabbling } \\
\text { ducks }\end{array}$ & & 596 & $60(10.1)$ & 884 & $129(14.6)$ \\
\hline TOTAL & Diving ducks & & 30 & 0 & 19 & $2(10.5)$ \\
\hline TOTAL & Gulls & & 599 & $22(3.7)$ & 614 & $52(8.5)$ \\
\hline
\end{tabular}

The number of birds examined and found virus positive (\%) are given for each species.

in 2007. The H6 subtype was the most common subtype found in ducks in this country in 2005 [7]. The most frequently occurring subtypes found in gulls in the present study were $\mathrm{H} 13$ and H16, although $\mathrm{H} 1$ and $\mathrm{H} 4-\mathrm{H} 6$ were also randomly found. H13 and H16 have only been found to infect gulls. In Common Gulls subtypes H6, H13 and H16 were detected, whereas subtypes H1, H5, H6, H13 and $\mathrm{H} 16$ were found in Herring Gulls, H4 and H13 in Black-headed Gulls, and H4 in Great Black-backed Gulls.

The NA subtype was determined in 78 of the 263 birds that tested positive for influenza A virus. The NA subtypes found in Norwegian wild birds were N1 (5 samples), N2 (29 samples), N3 (6 samples), N5 (2 samples),
N6 (14 samples) and N8 (12 samples). All samples were screened and all positive samples were sequenced directly from primary swab material, without prior virus isolation. Such a strategy might result in higher number of positive samples in screening surveys as compared to strategies where virus isolation is performed prior to RTPCR screening, as it is difficult to isolate virus from samples with low virus titer. However, sequencing of samples without prior virus isolation on samples with low titer is difficult when amplifying large fragments as using generic primers from HA and NA as attempted in this study. Thereby the proportion of subtypes determined in this study is relatively low. 
Table 2: Prevalence of influenza A virus, separated by month, in wild waterfowl in Norway 2006-2007.

\begin{tabular}{|c|c|c|c|c|}
\hline $\begin{array}{l}\text { Year } \\
\text { Month }\end{array}$ & $\begin{array}{c}2006 \\
\text { Ducks } \\
\text { No. of positive/ } \\
\text { No. of tested }\end{array}$ & $\begin{array}{c}2006 \\
\text { Gulls } \\
\text { No. of positive/ } \\
\text { No. of tested }\end{array}$ & $\begin{array}{c}2007 \\
\text { Ducks } \\
\text { No. of positive/ } \\
\text { No. of tested }\end{array}$ & $\begin{array}{c}2007 \\
\text { Gulls } \\
\text { No. of positive/ } \\
\text { No. of tested }\end{array}$ \\
\hline \multirow[t]{2}{*}{ August } & $2 / 102$ & $1 / 47$ & $14 / 186$ & $7 / 123$ \\
\hline & $1.9 \%$ & $2.1 \%$ & $7.5 \%$ & $5.7 \%$ \\
\hline \multirow[t]{2}{*}{ September } & $10 / 100$ & $5 / 92$ & $30 / 250$ & $24 / 270$ \\
\hline & $10 \%$ & $5.4 \%$ & $12 \%$ & $8.9 \%$ \\
\hline \multirow[t]{2}{*}{ October } & $23 / 137$ & $5 / 68$ & $43 / 204$ & $7 / 87$ \\
\hline & $16.8 \%$ & $7.4 \%$ & $21.1 \%$ & $8.0 \%$ \\
\hline \multirow[t]{2}{*}{ November } & $23 / 201$ & $2 / 101$ & $35 / 190$ & $13 / 100$ \\
\hline & $11.4 \%$ & $2.0 \%$ & $18.4 \%$ & $13 \%$ \\
\hline \multirow[t]{2}{*}{ December } & $2 / 86$ & $9 / 291$ & $9 / 73$ & $1 / 34$ \\
\hline & $2.3 \%$ & $3.1 \%$ & $12.3 \%$ & $2.9 \%$ \\
\hline \multirow[t]{2}{*}{ TOTAL } & $60 / 626$ & 22/599 & $131 / 903$ & $52 / 614$ \\
\hline & $9.6 \%$ & $3.7 \%$ & $14.5 \%$ & $8.5 \%$ \\
\hline
\end{tabular}

The table gives the number of positive samples, the total number of samples tested as well as the prevalence in percent.

In this study we report a higher prevalence of influenza A virus in wild birds than has been reporter from other countries in Europe [3]. Similar prevalence of infected wild birds has been observed in Sweden and North America [3,15]. This might suggest that the ecological system with breeding areas and temperatures in these countries is favourable for replication of influenza A virus in wild birds and transmission of influenza A virus among the wild birds.

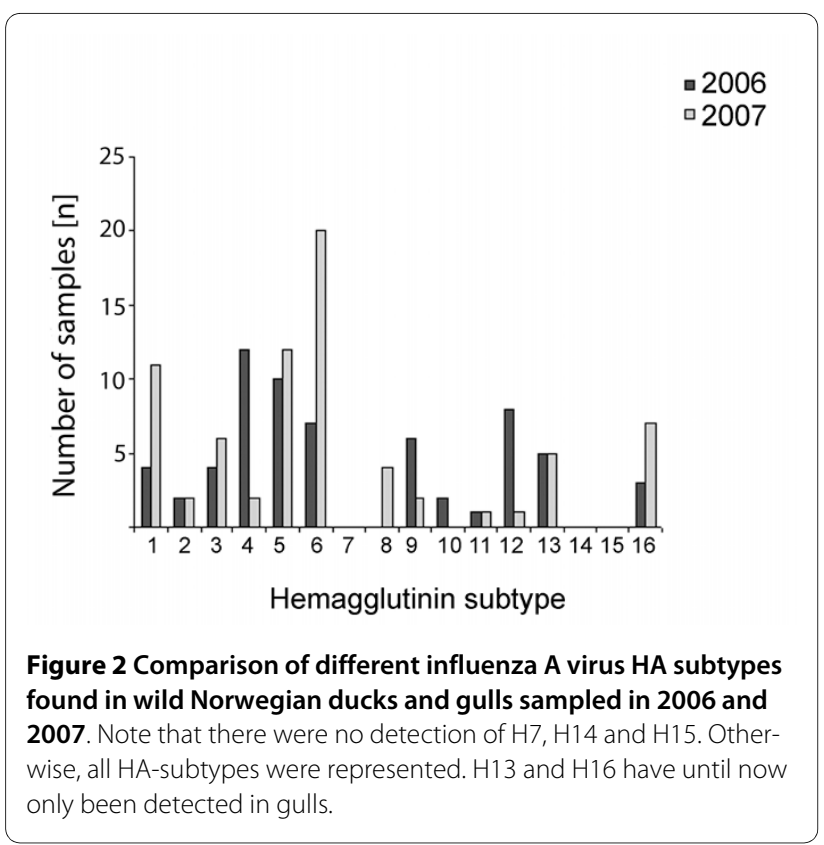

\section{Competing interests}

The authors declare that they have no competing interests.

\section{Authors' contributions}

AG and MJH carried out the real-time RT-PCR, RT-PCR, sequencing analysis, and interpretation of data. KIM was responsible for the logistics and collection of samples. CMJ and $\mathrm{KH}$ participated in the design of the study. AG and $\mathrm{KH}$ drafted the manuscript. All authors read and approved the final manuscript.

\section{Acknowledgements}

Thanks are due to all hunters who provided the samples, to Faisal Suhel, Kristin Soetaert, Lone Thiel Engerdahl, Sonja Ylving and Marthe Opland for excellent technical assistance and Dr Carl Spetz for valuable comments on the manuscript. This project was carried out as part of the National Avian Influenza Virus Surveillance Programme in Wild Birds funded by the Norwegian Food Safety Authority.

\section{Author Details}

'Department of Animal Health, National Veterinary Institute, P.O Box 750 Sentrum. N-0106 Oslo, Norway and ${ }^{2}$ Center for Laboratory Medicine, Akershus University Hospital, N-1478 Lørenskog, Norway

Received: 7 February 2010 Accepted: 28 April 2010 Published: 28 April 2010

\section{References}

1. Webster RG, Bean WJ, Gorman OT, Chambers TM, Kawaoka Y: Evolution and ecology of influenza A viruses. Microbiol Rev 1992, 56:152-179.

2. Fouchier RA, Munster V, Wallensten A, Bestebroer TM, Herfst S, Smith D, Rimmelswaan GF, Olsen B, Osterhaus AD: Characterization of a novel influenza A virus hemagglutinin subtype (H16) obtained from blackheaded gulls. JVirol 2005, 79:2814-2822.

3. Munster VJ, Baas C, Lexmond P, Waldenström J, Wallensten A, Fransson T, Rimmelzwaan GF, Beyer WEP, Schutten M, Olsen B, Osterhaus ADME, Fouchier RAM: Spatial, temporal, and species variation in prevalence of influenza A viruses in wild migratory birds. PLoS Pathog 2007, 3:630-638.

4. Keawcharoen J, van Riel D, van Amerongen G, Bestebroer T, Beyer WE, van Lavieren R, Osterhaus ADME, Fouchier RAM, Kuiken T: Wild ducks as long- 
distance vectors of highly pathogenic avian influenza virus (H5N1). Emerg Inf Dis 2008, 14:600-607.

5. Kilpatrick AM, Chmura AA, Gibbons DW, Fleischer RC, Marra PP, Daszak P: Predicting the global spread of H5N1 avian influenza. Proc Natl Acad Sci USA 2006, 103:19368-19373.

6. Krauss S, Obert CA, Franks J, Walker D, Jones K, Seiler P, Niles L, Pryor SP, Obenauer JC, Naeve CW, Widjaja L, Webby RJ, Webster RG: Influenza in migratory birds and evidence of limited intercontinental virus exchange. PLOS pathog 2007, 3:e167.

7. Jonassen $C M$, Handeland $\mathrm{K}$ : Avian influenza virus screening in wild waterfowl in Norway, 2005. Avian Dis 2007, 51:425-428.

8. Spackman E, Senne DA, Myers TJ, Bulaga LL, Garber LP, Perdue ML, Lohman K, Daum LT, Suarez DL: Development of a realtime reverse transcriptase PCR assay for type A influenza virus and the avian $\mathrm{H} 5$ and H7 hemagglutinin subtypes. J Clin Microb 2002, 40:3256-3260.

9. Slomka MJ, Pavlidis T, Banks J, Shell W, McNally A, Essen S, Brown IH: Validated $\mathrm{H} 5$ Eurasian real-time reverse transcriptase-polymerase chain reaction and its application in H5N1 outbreaks in 2005-2006. Avian Dis 2007, 51:373-377.

10. Phipps LP, Essen SC, Brown IH: Genetic subtyping of influenza A viruses using RT-PCR with a single set of primers based on conserved sequences within the HA2 coding region. J Virol Methods 2004, 122:119-122.

11. Hoffmann E, Stech J, Guan Y, Webster RG, Perez DR: Universal primers for the full-length amplification of all influenza A viruses. Arch Virol 2001, 146:2275-2289.

12. Parmley EJ, Bastien N, Booth TF, Bowes V, Buck PA, Breault A, Caswell D, Daoust PY, Davies JC, Elahi SM, Fortin M, Kibenge F, King R, Li Y, North N, Ojkic C, Pasick J, Pryor SP, Robinson J, Rodrigue J, Whitney H, Zimmer P, Leighton FA: Wild bird influenza survey, Canada, 2005. Emerg Infect Dis 2008, 14:84-87.

13. Stallknecht DE, Kearney MT, Shane SM, Zwank PJ: Effects of $p H$, temperature and salinity on persistence of avian influenza viruses in water. Avian Dis 1990, 34:412-418.

14. Webster RG, Yakhno M, Hinshaw VS, Bean WJ, Murti KG: Intestinal influenza: replication and characterization of influenza viruses in ducks. Virology 1978, 84:268-278.

15. Hanson BA, Stallknecht DE, Swayne DE, Lewis LA, Senne DA: Avian influenza viruses in Minnesota ducks during 1998-2000. Avian Dis 2003, 47:867-871.

Submit your next manuscript to BioMed Centra and take full advantage of:

- Convenient online submission

- Thorough peer review

- No space constraints or color figure charges

- Immediate publication on acceptance

- Inclusion in PubMed, CAS, Scopus and Google Scholar

- Research which is freely available for redistribution 